\title{
Kepemimpinan dan Organisasi: Pengembangan Sumber Daya Anggota Koperasi Berbasis Kewirausahaan
}

\author{
Ismail Suardi Wekke \\ Institut Agama Islam Negeri (IAIN) Sorong, Papua Barat \\ Email: iswekke@gmail.com
}

Ugrading Kepengurusan

Koperasi Mahasiswa Universitas Islam Negeri Alauddin Makassar

28-29 Maret 2020

Assalamu alaikum warahmatullai wabarakatuh

Saudara-saudari sekalian.

Alhamdulillah kita bisa berjumpa di media WA dalam rangkaian upgrading pengurus.

Hanya karunia Allah semata sehingga kita bisa Bersama dalam kegiatan ini. Di tengah wabah ini, semoga Allah memberikan kekuatan bagi kita untuk senantiasa tetap sehat walafiat.

Selanjutnya, sebuah kehormatan bagi saya untuk turut dalam diskusi kali ini.

Kehadiran saya, mudah-mudahan bisa menjadi ruang diskusi. Walau tak mudah. Sebab saya menjadi pengurus koperasi di 1998-1999. Sudah melewati 21 tahun.

Tentu sebuah tantangan bagi saya dan anda karena zaman yang kita hadapi saat ini berbeda.

Koperasi di zaman saya merupakan wadaj ekspresi. Sementara sekarang, anda semua punya banyak ruang kreasi yang mmeungkinkan. Maka, agenda kerja yang tentunya tidak ringan adalah bagaimana mahasiswa mau beraktifitas di koperasi mahasiswa.

Zaman saya, hanya ada telepon analog. Sementara sekarang semuanya digital, maka tentu koperasi bukan lagi wadah yang menarik, anda perlu membuatnya menjadi menarik.

Sekali lagi terima kasih kepada panitia dan pengurus kopma TB 2020, atas kesempatan berbagi.

Saya lanjutkan dengan tema Pendidikan dan SDA Koperasi sebagaimana amanat panitia.

Sebagai pengurus koperasi ada agenda mendesak yang harus anda bangun, yaitu kemauan dan kemampuan bersinergi.

Kadang disebut juga kolaborasi.

Sebagai bangsa, kita bisa juara dunia dalam badminton. Itu karena dua saja pemainnya.

Sementara kalua sepakbola, terakhir kali kita mendapatkan medali emas di level asia tanggara pada tahun 1991.

Apa yang saya mau kemukakan adalah kemampuan kerjasama. 
Sebagai individu, ada semua sudah mendapatkan porsi masing-masing dimana sebagai pengurus sudah terbago dalam pelbagai divisi atau departemen.

Setiap departemen menjadi bagian penting bangunan organisasi. Kalian semua sama pentingnya. Ini adalah kesempatan untuk saling memperkuat dan saling bekerjasama.

Tidak aka nada kepengurusan yang berjalan dengan baik, kalau semuanya tidak berpartisipasi.

Hindari sifat egois, jangan mementingkan kepentingan diri sendiri. Apalagi kalua terjebak pada pencitraan semata.

Hal utama dan pertama adalah kemampuan dan kemauan untuk saling memperkuat. Bukan sekadar hanya mengkritik saja tetapi kemampuan memberi solusi.

Kembali soal sinergi atau kolaborasi. Dengan bekerja sesuai fungsi kita masing-masing, tentu kepengurusan kopma TB 2020 akan solid.

Satu kemampuan yang harus dibangun adalah komunikasi. Jangan sampai, justru yang muncul adalah masing-masing bicara sendiri sehingga tidak solid.

Tentu dibutuhkan ketua umum yang mampu memjadi dirigen.

Masing-masing orang punya potensi sendiri, maka ketua umum memberikan aba-aba dan kesempatan untuk semuanya bersuara.

Dengan nada yang berbeda, tetapi tujuan yang sama.

Maka, jangan paksakan seorang pemain gitar untuk memainkan drum. Atau sebaliknya.

Kenali masing-masing, potensi anggota yang menjadi pengurus.

Mereka akan memberi dukungan secara total kalua diberi kesempatan. Maka, ketua umum jangan hanya bermain sendiri tetapi mendistribusikan semua informasi dan juga kekuatan untuk Bersama-sama membangun kopma.

Terakhir, soal digital.

Anda semua lebih faham dibanding saya. Hanya saja, saya sampaikan bahwa hidup di dunia maya harus sama dengan dunia nyata. Jangan sampai kehidupan di dunia maya berbeda dengan kehidupan dunia nyata.

Saatnya untuk melakukan transformasi digital dari analog terutama dalam memberikan maklumat kepada dunia tentang kopma.

Demikian, sementara paparan saya.

Terima kasih moderator. Saya serahkan kembali ke moderator

Wa alaikum salam warahmatullahi wabarakatuh

Terima kasih Anwar... 
Pertama kenali dulu karakter mahasiswa sekarang. Mulai dengan membuat pooling atau diskusi untuk menjawab pertanyaan "apa karakter mahasiswa sekarang?" setelah mengenal mereka, lanjutkan dengan menjawab pertanyaan "apa kebutuhan mahasiswa?".

Kalua pengawas SDA bisa melakukan itu rutin, maka dalam jangka waktu 2-3 minggu bahkan satu bulan sudah terjawab, apa rencana aksi yang akan dilakukan.

Mahasiswa datang ke kopma tentu karena ada yang menarik. Coba diskusikan "apa program kerja yang memungkinkan sehingga mahasiswa mau datang ke kopma”.

Dengan program kerja yang menarik, maka mahasiswa baik baru maupun mahasiswa lama akan merasa penting untuk menjadi koperasi.

Sebagai contoh, kalau kartu anggota kopma dapat dijadikan sebagai kartu diskon.

Ada alumni kopma yang sudah punya usaha. Coba nego dengan mereka.

Kalau pakai kartu anggota kopma, bisa dapat diskon berapa. Ini tentu bisa menjadi daya Tarik menjadi anggota kopma dan memegang kartu keanggotaan yang dibuktikan dengan membayar simpanan wajib.

Dalam konteks sumber daya anggota, "apa menjadi kebutuhan mahasiswa?" saya jawab "selesai tepat waktu"

Maka, itu bisa dilakukan dengan mengkreasi kegiatan-kegiatan mempercepat penyelesaian studi.

Terkait dengan kegiatan saya, maka horizon saya yang terbatas saya melihat bagaimana melatih mahasiswa untuk mampu menulis skripsi.

Itu yang kadang menghambat.

Tinggal diintegrasikan dengan isu keusahawanan ataupun koperasi. Bagaimana mereka menjadi entrepneur sekaligus juga bisa menulis.

Untuk menjadi entrepneur yang baik, maka tentu harus menguasai kemampuan menulis.

Itu yang bisa dilakukan oleh pengawas PSDA dalam kaitan mahasiswa secara umum.

Setelah ini, Anwar dan kawan-kawan boleh membuat kegiatan dalam bentuk penulisan skripsi. Ada Zul yang lulusan UniSZA, Malaysia.

Saya juga akan menyempatkan waktu khusus untuk kalian. Semoga dalam tahun ini bisa kita adakan penerimaan anggota sekaligus ada materi menulis akademik. Bisa disponsori oleh Mendeley.

Oleh Mendeley, saya itu Advisor. Sehingga memiliki ororitas untuk memohon sekadar merchandise untuk para peserta berupa gody bag dan juga souvenir.

Itu jawaban saya Anwar.

Terima kasih Khairun Nisa (perempuan sebaik-baik perempuan). 
Apa yang bisa dilakukan semester ini?

Saya terpikir untuk melatih kemampuan digital mahasiswa. Dalam hal ini anggota kopma. Maka, mahasiswa dilatih dengan terjadwal untuk memperkuat kapasitas mereka menggunakan perangkat digital.

Termasuk tadi, kemampuan menulis bisa dilakukan dengan mulai membaca artikel, lalu menonton video bisa melalui platform youtube.

Sederhananya, di masa-masa wabah ini kita tetap harus produktif. Tidak boleh berdiam diri. Itu akan memacu stress.

Untuk itu, media digital harus dimaksimalkan sebanyak mungkin sehingga bisa membantu mahasiswa untuk tetap belajar.

Tapi belajar bukan berarti tugas ya. Tetapi berakitivitas Bersama.

Oleh karena itu, sampai akhir semester, insya Allah ada ruang-ruang kreasi kita Bersama.

Sehingga selesai upgrading ini, pengurus silahkan berembug kegiatan apa saja yang memungkinkan untuk dilaksanakan.

Bisa juga persiapan studi lanjut. Kalau ada yang punya minat untuk kuliah magister terutama di UniSZA, tempatnya kak Zul selesai, saya dan kak Zul bisa membantu lebih awal.

Saya ada peluang untuk satu beasiswa, terutama dari FEBI. Akan diberikan beasiswa untuk 4 semester. Kita bisa cari dari anggota kopma bagi yang berminat untuk lanjut dengan beasiswa dari UniSZA.

Itu jawaban saya Khairun Nisa. Terima kasih atas responnya.

Terima kasih Ketua Umum. Ghena...

Soal transformasi. Perlu transformasi kopma dan juga anggotanya untuk mulai menguasai kemahiran digital.

Jangan lagi, menjadikan alas an UIN sebagai ketertinggalan.

Justru dengan status UIN yang perguruan tinggi Islam sebuah kesempatan menguasai urusan akhirat dan sekaligus permasalahan dunia.

Maka, paling penting adalah jangan sampai rendah diri. Rendah hati itu wajib, tetapi minder jangan sampai.

Terlalu banyak bukti yang bisa dilihat. Betapa alumni UIN Alauddin bisa bersanding dengan perguruan tinggi lain. Maka, tetap rendah hati, tapi singkirkan rendah diri.

Dari mana kita bisa memulai untuk mempersiapkan hal tersebut? 
Sosialisasi dalam KIE, komunikasi infomasi, dan edukasi. Dalam kondisi sekarang, pengurus kopma perlu berkolaborasi dengan studio atau tenaga humas supaya bisa membuat video yang atraktif. Sehingga bisa menginformasikan kegiatan-kegiatan kopma ke public.

Apa tujuannya? Supaya mahasiswa tertarik untuk menjadi anggota kopma.

\section{Apakah tim riset perlu kita bentuk di staf PSDA ?}

Bisa juga. Ini satu kesempatan untuk membuat program berbasis riset. Bahkan dengan platform digital kita bisa riset. Setelah ini, saya akan telusuri kembali ada buku saya dengan judul "Teknik Menulis karya ilmiah, dengan 8 senjata aplikasi produktivitas riset”.

Itu bisa menjadi referensi dalam melaksanakan aktivitas riset.

3. Moetode atau teknologi seprti apa yg bisa dipakai dalam mengumpulkan sebuah data yang akurat?

Banyak. Salah satunya Google Form. Karena hanya dengan menggunakan akun Google bisa diminta peserta penelitian untuk mengisi data yang diperlukan.

Bisa juga melalui survey di Facebook. Itu juga akurat, belum lagi ada Twitter.

Masa sekarang ini, mengumpulkan data sangat mudah karena tidak perlu menyebarkan kuisioner secara langsung.

Terima kasih Ketum, itu jawaban saya.

Pertanyaan dari Zul.

Kondisi kampus tentu berbeda atas apa yang saya alami dengan sekarang. Namun, birokrasi kampus tentu tidak bisa dijadikan lawan, melainkan mitra.

Apakah di rektorat masih ada kak Lina Sandol? Beliau itu sangat baik, membantu keperluankeperluan kopma ketika itu.

Termasuk memberi kawan-kawan pengurus dan juga saya beasiswa. Nilainya perbulan, fantastis. Ukuran sekarang saja uang 5 juta itu banyak. Apalagi tahun 98. 5 juta tiap bulan selama setahun.

Tips dari saya sederhana, kenali orang-orang di rektorat. Lakukan kegiatan yang mendekatkan antara pengurus kopma dengan birokrasi kampus. Maka, itu bisa berjalan Bersama-sama.

Mereka adalah mitra, sehingga jangan dijauhi. Untuk itu, kembali ke pola lama yang tetap relevan sampai sekarang. Komunikasi.

Gunakan seluruh media komunikasi untuk menyampaikan pesan ke rektorat. Paling sederhana menggunakan hastag.

Berapa anggota kopma? Sebagai contoh 100 orang. Kalau 100 orang itu pakai hastag yang sama setiap hari, maka akan menggaungkan kopma.

Bahkan bisa jadi orang luar juga akan penasaran. Apa arti hastag yang sementara trending. 
Itu jawaban saya, Zul. Namun, adek-adek pengurus kopma lebih paham bagaimana berkomunikasi di era digital sekarang ini.

Terakhir, saudara-saudari sekalian.

Sekali lagi terima kasih panitia dan pengurus atas kesempatan berharga ini.

Kawan-kawan yang bermedsos di Instagram, bisa tambahkan saya dengan akun ini: https://www.instagram.com/iswekke/.

Sebagai penutup pertemuan ini, ber-kopma adalah kesempatan untuk mempersiapkan diri di masa yang akan datang.

Apa yang saya capai saat ini, tentu tidak lepas dari dukungan kopma, baik anggota maupun pengurus ketika itu.

Sehingga saya menyambut dengan gembira ketika ketua umum menyampaikan ke saya kegiatan ini.

Selanjutnya, anda semua perlu membangun profil di dunia digital dengan baik.

Jangan mengetikkan apapun di media social yang menurut anda justru rahasia.

Dalam konteks kewirausahaan, justru media social itu menjadi pintu bagi rejeki. Sehingga jangan menutup pintu rejeki anda dengan postingan yang alay atau bahkan tidak patut dalam ukuran agama maupun adat istiadat kita.

Sekali lagi, terima kasih semuanya... selamat bekerja, yakinlah bahwa apa yang anda usahakan bukan untuk orang lain. Tetapi untuk anda sendiri.

Saya perlu ingatkan bahwa kopma itu kumpulan orang. Bukan kumpulan modal.

Maka, anda semualah yang menjadi soko-guru kopma bukan uang yang menjadi pilarnya.

Sehingga apapun masalah, selesaikan dengan komunikasi.

Terima kasih, mohon maaf atas segala kekurangan. 